\title{
PERAN MEDIA MASSA DALAM PENINGKATAN PARTISIPASI PEMILIH PEMULA PADA PILKADA 2013 DI KECAMATAN TEMPE KABUPATEN WAJO
}

\author{
Hardini Hasanuddin ${ }^{1}$, Muhammad Yusuf Badjido ${ }^{2}$, Rudi Hardi ${ }^{1}$ \\ ${ }^{1}$ Program Studi Ilmu Pemerintahan Fakultas Ilmu Ssosial dan Ilmu Politik \\ Universitas Muhammadiyah Makassar \\ Jl Sultan Alauddin No 259 Makassar 90221 \\ Telp. 0411-866972 ext. 107. Fax. 0411-8655888 \\ hardini h@yahoo.com rudi hardi@gmail.com \\ ${ }^{2}$ Program Studi Ilmu Adminitrasi Negara Fakultas Ilmu Sosial dan Ilmu Politik \\ Universitas Muhammadiyah Makassar \\ Jl Sultan Alauddin No 259 Makassar 90221 \\ Telp. 0411-866972 ext. 107. Fax. 0411-8655888 \\ yusufbadjido@gmail.com
}

\begin{abstract}
Mass media is one of the factors that may affect the level of participation of voters in a local election. Based on this, the researchers were motivated to prove that the mass media have an important role in increasing the participation of voters in the local elections in 2013 in District Tempe Wajo. This research is a qualitative descriptive to decipher and interpret the data obtained from the process of organizing and sorting the data obtained from the field and from informants who were 18 people into patterns, categories, and a basic outline that can be found themes and formulated the working hypothesis the results of the study show the influence of the mass media of increasing participation of voters in the 2013 election in District Tempe Wajo. Such increase is influenced by factors; information.
\end{abstract}

Keywords: The mass media, participation, voters

\begin{abstract}
ABSTRAK
Media Massa merupakan salah satu faktor yang dapat memepengaruhi tingkat partisipasi pemilih pada suatu pemilihan kepala daerah. Berdasarkan hal tersebut, peneliti termotivasi untuk membuktikan bahwa media massa mempunyai peran penting dalam peningkatan partisipasi pemilih pemula pada pemilihan kepala daerah 2013 di Kecamatan Tempe Kabupaten Wajo. Jenis penelitian ini adalah Deskriptif Kualitatif dengan menguraikan serta menginterprestasikan data yang diperoleh dari proses mengorganisasikan dan mengurutkan data yang di peroleh dari lapangan dan dari para informan yang berjumlah 18 orang kedalam pola, kategori, dan suatu uraian dasar sehingga dapat di temukan tema dan dirumuskan hipotesis kerja.Hasil penelitian menunjukkan adanya pengaruh media massa terhadap peningkatan partisipasi pemilih pemula pada pilkada 2013 di Kecamatan Tempe Kabupaten Wajo. Peningkatan tersebut sangat di pengaruhi oleh faktor; informasi.
\end{abstract}

Kata kunci :Media massa, partisipasi, pemilih pemula 


\section{A. PENDAHULUAN}

Desenrtalisasi dan kebebasan informasi bangkitnya industri pers lokal telah memberikan kontribusi dan warna baru dalam tradisi bermedia dan kehidupan demokrasi di Indonesia. Berdasarkan pasal 33 Undang-Undang No.40 Tahun 1999 tentang pers dimana berbunyi fungsi pers adalah sebagai media informasi, pendidikan, hiburan, dan kontrol sosial. Namun demikian, kehidupan bermedia,terutama di ranah lokal masih menunjukkan karut marut persoalan berkelindan dan pelik untuk diurai. Netralisasi pers lokal dalam pemilihan kepala daerah (pilkada) misalnya, para kandidat berlombalomba memasang iklannya di media massa untuk menarik perhatian masyarakat. Juga dalam Undang-Undang Pemilu No.12 Tahun 2003 Pasal 73 dimana berbunyi bahwa media eletronik dan media cetak wajib memberikan kesempatan yang sama kepada peserta pemilu untuk memesang iklan pemilu dalam rangka kampanyenya.

Pemilihan umum adalah salah satu pilar utama dari sebuah demokrasi, salah satu konsepsi modern diajukan oleh joseph scumpeter (2005), dikutip oleh S.H Sarundajang (2012:66) yang menempatkan penyelenggaraan pemilihan umum yang bebas dan berkala sebagai kreteria umum bagi sebuah sistem politik agar dapat disebut sebagai sebuah demokrasi.

Menyongsong pemilihan Bupati yang sukses salah satu pemegang kunci keberhasilan adalah peranan media, Karna arus informasi yang cepat dan meluas di dapat melalui media.

Walaupun dengan jumlah pemilih yang tidak seberapa dibandingkan dengan pemilihan Gubernur pada tingkat provinsi, namun dengan 14 Kecamatan dan 166 Desa maka dalam pelaksanaan pemelihan Bupati di Kabupaten Wajo tidak semudah membolak balikkan telapak tangan, terutama untuk kandidat Calon bupati dan calon wakil bupati yang harus melaksanakan kampanye di 14 Kecamatan yang secara geografis satu dengan yang lain sangat sulit untuk di tempuh. Dengan demikian media lokal adalah pilihan yang sangat efektif untuk dapat di manfaatkan sebagai corong agar visi dan misi dari para kandidat dapat diketahui atau dibaca oleh para calon pemilih. Akan tetapi banyak kandidat calon bupati dan calon wakil bupati yang mengikuti pilkada membuat persaingan memperebutkan suara terbanyak menjadikan masyarakat semakin sulit menentukan pilihannya, salah satunya karena timbulnya rasa ketidakpastian, terutama bagi bagi pemilih pemula yang di gambarkan dari golongan remaja yang karna usianya baru bisa memilih, karena itu kandidat harus mengkomunikasikan dengan cara memperkenalkan dan mengsosialisasikan diri kepada masyarakat secara terus-menerus sarana sosialisasi yang dapat digunakan adalah iklan di media massa karena kemampuan media mempengaruhi khalayak upaya komunikasi di harapkan mampu memberikan informasi bagi pemilih pemula untuk mengurangi rasa ketidakpastian.

Meski demikian peran media tersebut dalam mempengaruhi sikap dan prilaku khalayak pemilih pemula terhadap pilkada. Proses pembentukan sikap di pengaruhi oleh beberapa faktor, yaitu adalah media massa sebagai sumber imformasi seperti televisi, radio, surat kabar, majalah, buletin, dan lainlain. Oleh karena itu di perlukan media massa yang independen media yang memberikan informasi yang benar, relevan, dan objektif bagi masyarakat.Kehadiran media yang independen dapat mengarah pada dua peran pertama menjadi anjing penjaga 
bagi pemerintah, kedua mengedukasi publik atas berbagai isu yg berpengaruh terhadap kehidupan mereka sehari-hari.

Interaksi ini terlihat di banyak sektor kehidupan dalam konteks yang lebih politis, pemilu misalnya, sebagian besar mengunakan media sebagai sumber informasi pemilihan umum dengan demikian ini tentu sangat membuka penyalahgunaan media sebagai sarana "main mata"antara pemilik media dan elit politik daerah.

Penjualan rubrik oleh media cetak(koran, tabloid, buletin, dan majalah) kepada calon kandidat, yang kemudian isi rubrik itu hanya memuat kegiatan-kegiatan sosial kepada masyarakat. Kemudian ini disetting sedemikian rupa dengan sempurna sehingga tidak terlihat tujuan media tersebut adalah mempromosikan salah satu calon melalui kegiatan sosial. Publik tentu akan mengasumsikan bahwa hal tersebut murni berita, padahal dibalik semua itu adalah kampanye politik agar publik bersimpati, melalui suguhan berita yang hal positif saja publik tentu akan jatuh cinta kepada calon yang beritanya lebih banyak dimuat. Seorang kandidat membeli dan mengisi rubrik media cetak lebih dari lima media yang ada maka secara langsung sang calon akan lebih familiar di mata masyarakat umumnya dan pada calon pemilih khususnya. Proses pemembetukan dan perubahan sikap, peranan media massa sangat besar pengaruhnya dalam peningkatan partisipasi calon pemilih walaupun tidak sebesar interaksi masyarakat secara langsung. Masyarakat yang memilih demokrasi sebagai sistem kenegaraannya, pemilu merupakan salah satu tonggak demokrasi dan instrumen untuk mewujudkan cita-cita demokrasi yaitu terbentuknya masyarakat yang adil, makmur, sejahtera, memiliki kebebasan berekspresi dan berkehendak serta mendapatkan akses terpenuhinya hakhak dasar mereka sebagai warga negara karena itu untuk melihat ada tidaknya demokrasi dalam penyelenggaraan negara, indikatornya dapat dilihat dari pemilu yang dilakukan secara bebas dan berkesinambungan.

Setiap warga negara, apapun latar belakangnya seperti suku, agama, ras, jenis kelamin, status sosial dan golongan, sesungguhnya mereka semua memiliki hak yang sama untuk berserikat dan berkumpul, menyatakan pendapat, menyikapi secara kritis kebijakan pemerintah dan pejabat negara. Hak ini disebut hak politik yang secara luas dapat langsung diaplikasikan secara kongkrit melalui media pemilihan umum.

Penyelenggaraan pemilu diperlukan tata cara dan prosedur yang disebut sistem pemilu. Sistem pemilu mencakup dua hal. Pertama, nilai-nilai normatif yang tertuang dalam UndangUndang Pemilu yang mengatur bagaimana membagi kekuasaan dalam lembaga perwakilan secara proporsional sesuai dengan dukungan politik yang tergambar dari hasilperolehan suara dalam pemilu.Kedua, proses pemilihan yaitu mekanisme pemilihan yang meliputi pengelolaan pemilu, pemilihan $\mathrm{di}$ tempat suara pemungutan suara, perhitungan suara, petugas pemilu, penetapan hasil pemilu dan menetapkan hasil pemilu menjadi kursi di lembaga perwakilan maupun pada tingkat eksekutif.

Adapun pemilihan umum kepala daerah Kabupaten Wajo 2013 lalu telah di ikuti oleh enam pasang calon yang dimana pilkada ini juga merupakan pilkada secara langsung yang untuk kedua kalinya di adakan untuk memilih Bupati dan Wakil Bupati Kabupaten Wajo.Dalam rangka usaha untuk 
memperoleh simpati masyarakat sehingga memperoleh suara sebanyakbanyaknya pada pilkada 2013 di Kabupaten Wajo, keenam kandidat berlomba-lomba melakukan kampanye, Kecematan Tempe merupakan Kecematan terluas dari empat belas Kecematan yang berada di Kabupaten Wajo, hal ini menjadikan Kecematan Tempe menjadi salah satu daerah yang diminati oleh keenam kandidat untuk dimenangkan.

Ada berbagai cara yang dilakukan oleh para pasangan kandidat untuk menarik simpati masyarakat Kecamatan Tempe dengan cara seperti konvoi damai, panggung terbuka, serta pemberian sumbangan pembangunan tempat-tempat umum seperti mesjid dan lain-lain yang berada di Kecamatan Tempe.

Adapun jumlah penduduk

Kecamatan Tempe yang terdaftar sebagai pemilih tetap pada pemilihan kepala daerah Kabupaten Wajo tahun 2013 berjumlah 50131 orang dengan jumlah laki-laki 23733 dan perempuan 26398 orang, itu sudah termasuk pemilih pemula.

\section{B. KERANGKA KONSEP}

Peran adalah merupakan salah satu komponen dari sistem sosial organisasi, selain norma dan budaya organisasi. Di sini secara umum peran dapat didefinisikan menurut Bauer (2007:55) dalam Haris (2012:204) sebagai presepsi mengenai cara orang itu diharapkan berperilaku atau dengan kata lain adalah pemahaman atau kesadaran mengenai pola prilaku atau fungsi yang diharapkan dari orang tersebut.

Dari defenisi di atas dapat dikatakan bahwa peran adalah suatu konseptual yang melibatkan penciptaan produk sebagai lawan dari prilaku atau tindakan atau bisa dikatan suatu peran itu akan bergantung pada penekanan peran tersebut oleh para penilai dan pengamat.

Haris (2012:212) mengemukakan peran berarti laku, bertindak, peran adalah perangkat tingkah laku yang diharapkan dimiliki oleh orang yang berkedudukan atau memegang kekuasaan. Dari peryataan di atas dapat dijelaskan menurut historis atau sejarah konsep peran adalah karakter yang disandang atau dibawakan oleh seorang aktor dalam sebuah pentas. Sedangkan menurut ilmu sosial peran adalah suatu fungsi yang dibawakan seseorang ketika menududuki jabatan tertentu. Dari pendapat di atas disimpulkan peran adalah sesuatu yang mempunyai memiliki pengaruh sesuai dengan fungsinya.

Media massa adalah alat yang digunakan dalam menyampaikan informasi atau pesan dari sumber kepada khalayak dalam jumlah banyak (massa). Media massa merupakan suatu penemunan teknologi yang luar biasa, media massa adalah alat dalam komunikasi yang bisa menyebarkan informasi secara serempak, cepat kepada audience yang luas kelebihan media dibanding dengan jenis komunikasi yang lainnya adalah media massa bisa mngatasi hambatan ruang dan waktu. Bahkan media massa mampu.

Effendy (2009:21), media massa digunakan dalam komunikasi apabila komunikasi berjumlah banyak dan tempat tinggal yang jauh. Media massa yaitu alat komunikasi yang memungkinkan kita mengetahui suatu informasi sacara hampir bersamaan walaupun berada di tempat yang berbeda atau di tempat tinggal yang jauh menyebarkan hampir seketika pada waktu yang tak terbatas.

Pemahaman lebih lanjut tentang Media dapat ditinjau dari perkembangan teknologi menurut 
Crwaford yang di kutip Ida (2010:41) mengemukakan bahwa media massa dapat dibagi mnejadi dua jenis yaitu: Media massa modern, yang dimaksud media massa modern adalah media massa yang mengunakan teknologi modern yaitu media cetak dan media eletronik. Media massa cetak adalah media massa yang dalam menyampaikan informasinya terlebih dahulu harus di cetak menggunakan alat cetak. Media ini misalnya surat kabar, majalah, tabloid. Media massa eletronik adalah media massa yang dalam menyampaikan informasinya mengunakan jasa listrik, tanpa listrik media massa ini tidak dapat berfungsi.

Media massa dibedakan menjadi dua bentuk, yaitu media cetak dan media elektronik yaitu Media cetak dan Media elektronik selain itu jenis yang kedua adalah media tradisional yang digunakan sebagai sarana penyampaian informasi pada zaman dulu, lebih banyak mengunakan media massa tradisional misalnya wayang, lawak, lenong, dan seni tradisional lainya. Setiap jenis media massa mempunyai sifat-sifat khasnya oleh karna itu penggunaanya juga harus diperhitungkan sesuai dengan kemampuan dan sifat-sifat khasnya selain itu media secara mandiri maupun hanya sebagai penunjang memiliki fungsi sebagai berikut Sebagai Pemberi Informasi, Dapat Memperluas Cakrawala Pemikiran, Media sebagai pusat perhatian, Media mampu menumbuhkan aspirasi dan Media mampu menciptakan suasana membangun

Peran media massa sangat dekat komunikasi massa karena berfungsi sebagai saluran dari komunikasi massa.Istilah komunikasi massa kadangkadang telah diberikan defenisi di dalam dua cara menurut (Arifin, 2010:39) komunikasi melalui media dan komunikasi untuk umum. Namun demikian, komunikasi massa tidak berarti komunikasi yang pesanpesannya diterima setiap orang. Media cenderung menyeleksi khalayak dan sebaliknya, khalayak juga menyeleksi diantara dan didalam media. Berdasarkan pandangan di atas, dapat diartikan bahwa media massa adalah alat untuk mediator untuk berkomunikasi dengan masyarakat dalam ilmu komunikasi, media massa diartikan sebagai alat untuk berkomunikasi dengan massa yaitu pers (surat kabar dan majalah), radio, dan televisi.

Seperti yang dikemukakan di atas dapat diartikan bahwa media massa adalah alat, instrument komunikasi yang memungkinkan kita untuk merekam serta mengirim informasi dan pengalaman dengan cepat kepada masyarakat luas dan terpencar.

Media massa mampu mempengaruhi tindakan dan pemikiran khalayak antara lain dalam hal budaya, sosial, dan politik. Media dianggap memiliki peran yang sangat penting dalam mentransmisi dan menstimulasi permasalahan politik. Hal ini menjadi sangat penting dalam setiap kampanye politik. Cakupan yang luas dalam masyarakat membuat media massa dianggap sebagai salah satu cara yang efektif dalam mengkomunikasikan program kerja, pesan politik kepada pemilih.

Partisipasi adalah keikutsertaan, peranserta atau keterlibatan yang dengan keadaan lahirnya.Budiardjo (1994:81) Prinsip partisipasi adalah masyarakat berperan secara aktif dalam proses atau alur tahapan program dan pengawasannya, mulai dari tahap sosialisasi, perencanaan, pelaksanaan, dan pelestarian kegiatan dengan memberikan sumbangan tenaga, pikiran, atau dalam bentuk materil. 
Partisipasi merupakan salah satu aspek penting dalam perkembangan demokrasi.Asumsi yang mendasari demokrasi adalah bahwa setiap orang mengetahui diri dan dunianya lebih baik dari pada orang lain termasuk para ahli yang membuat keputusan.

Sementara itu Milbarth dalam Budiardjo (1994:89) membedakan partisipasi menjadi beberapa kategori, pertama apatis, artinya orang yang tidak berpartisipasi dan menarik diri proses politik. Kedua, spektator artinya orang yang setidak-tidaknya pernah ikut memilih dalam pemilihan umum. Ketiga, gladiator artinya mereka yang secara aktif ikut terlibat dalam proses politik, yaitu komunikator, spesialis megadakan tatap muka, aktifis pertai dan pekerja kampannye, dan aktifis masyarakat.

Ada beberapa faktor yang memepengaruhi tinggi rendahnya partisipasi politik seseorang. Pertama, kesadaran politik dan kepercayaan kepada pemerintah(sistem politik). Yang dimaksud dengan kesadaran politik adalah kesadaran akan hak dan kewajiban sebagai warga negara. Kedua, menyangkut pengetahuan seseorang tentang lingkungan masyarakat dan politik, dan menyangkut minat perhatian seseorang terhadap lingkungan masyarakat dan politik dia hidup. Yang dimaksud dengan sikap kepercayaan kepada pemerintah adalah penelitian seseorang terhadap pemerintah.

Pemilih menurut Sinaga (2003:118), adalah warga negara Indonesia yang telah genap berusia 17 tahun atau lebih atau sudah menikah/pernah kawin, pemilih dalam setiap pemilihan umum didaftarkan melalui pendataan yang dilakukan oleh petugas yang ditunjukkan oleh penyelenggara pemilihan umum. Pemilih pemula merupakan pemilih yang baru pertama kali memilih karena usia mereka baru memasuki usia pemilih yaitu 17 hingga 21 tahun. Pengetahuan mereka terhadap pemilu tidak berbeda jauh dengan kelompok lainnya yang membedakan adalah soal antusiaisme dan prefensi. Menurut Sekertaris Jendral KPU biro teknis dan Humas (2010).

Pemilih pemula khususnya remaja (berusia 17 tahun) mempunyai nilai kebudayaan yang santai, bebas, dan cenderunng pada hal-hal yang informal dan mencari kesenangan, sehinggah semua hal-hal yang mereka anggap kurang menyenangkan akan dihindari. Disamping mencari kesenangan, kelompok sebaya adalah paling penting dalam kehidupan seorang remaja, sehingga seorang remaja perlu mempunyai kelompok teman sendiri dalam pergaulan.

Adapun syarat-syarat yang harus dimiliki untuk menjadikan seseorang dapat memilih menurut Sekertariat Jendral KPU Biro Beknis dan Humas 2010 yaitu WNI yang berusia 17 tahun atau lebih atau sudah/pernah menikah, tidak sedang terganggu jiwa/ingatannya, terdaftar sebagai pemilih dan Bukan anggota TNI/Polri (Purnawirawan / sudah tidak lagi menjadi TNI/Kepolisian).

Dasar hukum yang mendasari pemilihan kepala daerah (pemulukada) ini dalah Amandemen Kedua (2002) Pasal 18 UUD 45, Ayat (4) " Gubernur, Bupati, dan Walikota masing-masing sebagai kepala daerah pemerintahan daerah provinsi, kabupaten, dan kota dipilih secara demokratis".

Pernyataan ini dapat ditafsirkan sebagai pemilihan kepala daerah bisa secara langsung dan tidak langsung. Tetapi karna tuntutan rakyat yang begitu besar untuk melaksanakan pemilihan langsung tidak saja pemilihan lansung untuk Presiden Wakil Presien, 
tetapi juga bagi Kepala Dearah Dan Wakil Kepala Daerah.

Dalam Peraturan Pemerintah Nomor 17 Tahun 2005 Tentang pemilihan, pengesahan, pengangkatan dan pemberhentian Kepala Daerah dan Wakil Kepala Daerah. Disebutkan bahwa yang di maksud dengan pemilihan kepala daerah adalah sarana pelaksanaan kedaulatan di wilayah provinsi dan/ wilayah kabupaten dan/ kota berdasarkan Pancasila dan Uundang-Undang Dasar Republik Indonesia Tahun 1945 untuk memilih Kepala Daerah dan Wakil Kepala Daerah.

Menurut Supono (2005:106), setidaknya ada 4 (empat) alasan mengapa penyelenggaran pilkada harus dilaksanakan secara langsung di daerah yaitu Pemilihan kepala daerah langsung adalah bagian dari penyelenggaraan pemerintahan daerah, Pemilihan kepala daerah secara langsung merupakan hak otonomi daerah, Dalam rangka memberikan tanggung jawab kepada daerah untuk menyelenggarakan proses demokrasi di tingkat lokal dan Memberdayakan daerah dalam rangka memeperkuat struktur pemerintahan dalam bangunan piramida, dimana pemerintahan nasional ditopang dengan sistem pemerintahan daerah yang kuat.

\section{METODE PENELITIAN}

Waktu penelitian ini dimulai dari bulan September sampai dengan November 2013. Lokasi penelitian ini dilaksanakan di Kecamatan Tempe Kabupaten Wajo. Kemudian Jenis penelitian yang digunakan pada penelitian ini ialah kualitatif, artinya data yang dikumpulkan bukan berupa angka-angka melainkan data tersebut berasal dari hasil wawancara, catatan lapangan, dokumen pribadi, catatan memo, dan dokumen resmi lainnya dan Tipe Penelitian ini dikategorikan sebagai penelitian tipe eksploratif dengan pendekatan

kualitatif.Pendekatan kualitatif dilakukan untuk mengungkapkan fakta faktual tentang peran media massa dalam peningkatan partisipasi pemilih pemula pada pilkada 2013 di Kecamatan Tempe Kabupaten Wajo. Sumber data yang digunakan ialah Data Primer dan data sekunder

Dalam penelitian ini yang menjadi informan ialah para pemilih pemula khususnya yang berusia 17-21 tahun atau pemilih yang baru pertama kali mengikuti pemilu, dan ketua maupun anggota KPU Kabupaten Wajo, KPPS Kecamatan Tempe, PANWASLU Kecamatan Tempe dan Teknik Pengumpulan data dan informasi sebagai bahan melakukan penelitian terhadap Peran media massa dalam peningkatan partisipasi pemilih pemula pada pilkada 2013 di Kacamatan Tempe Kabupaten Wajo. Untuk mendapatkan data yang akurat peneliti akan mengunakan tiga teknik pengumpulan data, yaitu observasi, wawancara dan dokumentasi

Tehknik analisis data yang digunakan dalam penelitian ini adalah analisis deskriptif kualitatif yaitu dengan menguraikan serta menginterprestasikan data yang di peroleh dari proses mengorganisasikan dan mengurutkan data yang diperoleh dari lapangan dan dari para informan kedalam pola, kategori, dan suatu uraian dasar sehingga dapat di temukan tema dan dirumuskan hipotesis kerja seperti yang disarankan oleh data. Ada tiga unsur utama dalam proses analisis data penelitian kualitatif, menurut Moleong (2005:89), yaitu: Reduksi Data adalah bagian dari proses analisis yang mempertegas, memperpendek dan membuang hal-hal yang tidak penting sehinggah kesimpulan penelitian dapat dilaksanakan. Jadi laporan lapangan sebagian bahan disingkat dan disusun 
lebih sistematis sehinggah lebih mudah dikendalikan.

Data yang direduksi memberi gambaran yang lebih tajam tentang hasil pengamatan, juga mempermudah peneliti untuk mencari kembali data yang diperoleh apabila diperlukan, Penyajian Data adalah susunan informasi yang memungkinkan dapat ditariknya suatu kesimpulan penelitian. Penyajian data dalam bentuk gambaran, skema, dan tabel mungkin akan berguna mendapatkan gambarkan yang serta memudahkan dalam penyusunan kesimpulan penilitian.

Pada dasarnya, sajian data dirancang untuk mengambarkan suatu informasi secara sistematis dan mudah dilihat serta dipahami dalam bentuk keseluruhan sajiannya, Kesimpulan merupakan hasil akhir dari reduksi data dan penyajian data.Kesimpulan penelitian merupakan verifikasi agar mantap dan benar-benar bisa dipertanggung jawabkan kebenarannya.

\section{HASIL DAN PEMBAHASAN}

\section{Peran Media Massa Dalam Peningkatan} Partisipasi Pemilih Pemula Pada Pilkada 2013 DI Kecamatan Tempe Kabupaten Wajo

Berkaitan dengan studi ini yang hanya berfokus pada peran media massa dalam peningkatan partisipasi pemilih pemula pada pilkada 2013 di Kecamatan Tempe Kabupaten Wajo, maka dalam hal peran media massa pada pilkada yang dianalisa hanya yang berkaitan dengan peningkatan partisipasi pemilih pemula di Kecamataan Tempe Kabupaten Wajo.

Fenomena politik menjelang diadakannya perhelatan pemilihan umum kepala daerah Kabupaten Wajo tahun 2013 lalu begitu mendominasi pemberitaan pada kolom-kolom media cetak maupun media siar di kota Sengkang. pada media cetak, hampir di setiap sudut kolom terhiasi oleh beragam pemberitaan mengenai
pilkada.Hal ini dapat kita lihat pada tabloid dan majalah yang terbit mingguan maupun bulanan yang beredar di Kabupaten Wajo edisi Juni sampai dengan September. Serta spanduk dan baliho yang terpajang disetiap sudut kota.

Proses pemilihan umum, baik pada tingkat pusat dan daerah, media massa merupakan salah satu wadah pemberi informasi yang harus ada. Media massa yang dimaksud disini ialah suatu media yang bertujuan untuk memberikan penjelasan kepada masyarakat akan maksud dan tujuan dari pemilihan umum tersebut.

Bagian ini peneliti akan memaparkan tentang penerimaan media serta pengaruh media terhadap peningkatan partisipasi pemilih pemula pada pilkada 2013 di Kecamatan Tempe Kabupaten Wajo. Dari hasil wawancara dan observasi mengenai tingkat intensitas penerimaan media yang yang berkenaan dengan pemberi informasi, memperluas pengetahuan, serta sebagai alat komunikasi pemilihan kepala daerah Kabupaten Wajo 2013 yang meliputi visual dan audio-visual baik media elektronik maupun media cetak.

\section{Pemberi Informasi}

Media massa yang tinggi tingkat penerimaannya di kalangan masyarakat di Kecamatan Tempe Kabupaten Wajo ialah Media radio. Media ini merupakan media yang mudah di dengarkan oleh masyarakat lapisan bawah selain itu radio juga dapat di dengarkan oleh masyarakat pedesaan sehingga selain sebagai pemberi informasi radio juga merupakan alat komunikasi, karna hampir di setiap rumah akan mudah di jumpai media elektronik ini. Namun karna biaya iklan cukup besar, maka intensitas penyiaran iklan melalui radio agak berkurang dan hanya kalangan tertentu saja yang bisa beriklan melalui media ini. Seperti halnya yang di 
katakan oleh salah satu staff bagian Humas KPU Kabupaten Wajo AR, bahwa: "Menyampaikan atau mensosialisasikan kepada masyarakat Kabupaten Wajo bahwa akan di laksanakan pilkada atau pemilihan bupati pada tanggal 18 September 2013, kami memang menggunakan jasa media audio di karnakan kami beranggapan bahwa dengan memberi himbauan melalui penyiaran radio dapat cepat di ketahui oleh masyarakat baik yang berdomisili di Kota Kabupaten, pinggirian kota, dan masyarakat pedalaman." wawancara AR).

Pernyataan di atas menunjukkan adanya media audio merupakan salah satu media yang digunakan untuk memberikan informasi kepada khalayak yang berkenaan dengan pemilihan kepala daerah 2013 di Kabupaten Wajo. Secara bersamaan dapat di dengar oleh masyarakat yang bertempat tinggal di kota kabupaten dan yang di pedalaman secara serentak walaupun berada di tempat yang berbeda dan dapat pula di dengarkan oleh semua lapisan masyarakat dari masyarakat menengah ke bawah.

2. Memperluas Pengetahuan

Media audio-visual atau televisi juga merupakan media yang memiliki peranan yang cukup besar dalam menyampaikan informasi serta dapat memperluas pengetahuan yang berkenaan dengan pemilihan kepala daerah 2013 di Kabupaten Wajo baik itu kampanye calon pasangan maupun himbauan intansi terkait. Hal ini terbukti dari hasil observasi dan wawancara dengan informan bahwa mereka pernah melihat iklan yang berkenaan dengan pemilihan kepala daerah 2013 di Kabupaten Wajo.
Walaupun hanya sekali dikarnakan channel televisi yang menyiarkannya merupakan channel lokal. Seperti yang di katakan oleh KW 19 tahun pemilih pemula Kelurahan Siengkang Kecamatan Tempe Kabupaten Wajo, bahwa :

"Saya pernah melihat salah satu pasangan calon bupati Wajo di televisi berkampanye meminta untuk di dukung pada pemilihan bupati tanggal 18 September 2013, tapi cuma satu kali karna kami di rumah jarang menonton tv Channel Wajo karena siarannya tidak begitu bagus". (wawancara KW).

Dari hasil wawancara diatas dapat di simpulkan bahwa channel televisi lokal tidak begitu di minati oleh masyarakat di karnakan acara yang disiarkan tidak menarik bagi sebahagian masyarakat sehingga tingkat penerimaan media channel televisi tidak begitu baik di tengah masyarakat Kecamatan Tempe.

\section{Alat Komunikasi}

Media cetak Berbeda dengan media elektronik, media cetak seperti koran, majalah, baliho, sanduk, dan stiker ternyata memiliki porsi penerimaan yang sangat tinggi di banding dengan media elektronik baik media audio maupun audio-visual. Sebagian besar informan mengaku pernah bahkan sering memperhatikan iklan pemilihan kelapa daerah 2013 di Kabupaten Wajo serta mendapatkan informasi serta pengetahuan dari membaca serta memperhatikan spanduk serta koran. Sebagian besar informan tersebut mengaku memperhatikan iklan tersebut di majalah lokal dan spanduk serta baliho baik yang dipajang maupun yang disebarkan dan iklan kampanye pasangan calon hingga himbauan intansi terkait dengan pemilihan kepala daerah 
2013 di Kabupaten Wajo. Dari hasil wawancara dan observasi dapat di simpulkan bahwa Akses informasi media cetak seperti baliho, spanduk dan stiker ke masyarakat kalangan menengah ke bawah merupakan merupakan media yang sangat tinggi tingkat penerimaannya dalam memperluas pengetahuan serta sebagai alat komunikasi massa kepada masyarakat di bandingkan dengan media elektronik dikarnakan media ini bisa di temukan atau di akses dengan mudah. Seperti halnya yang dikatakan MA 20 Tahun pemilih pemula Kelurahan Tempe Kecamatan Tempe Kabupaten Wajo, bahwa :

"Saya mengetahui bahwa akan ada pemilihan Bupati Wajo pada tanggal 18 September 2013 karna saya sering melihat dan membaca spanduk maupun stiker yang di tempel di dinding toko atau di tiang listrtik biasa juga di pasang di pos ronda. Selain itu saya juga biasa di ajak tetangga ikut memasang baliho salah satu pasangan kandidat". (Wawancara MA).

Hasil wawancara mempertegas bahwa media massa seperti spanduk dan baliho sebagai alat komunikasi yang tinggi tingkat penerimaannya di kalangan masyarakat di karnakan media massa seperti baliho, sktiker, dan spanduk mudah ditemukan tanpa ada biaya sehingga media ini lebih banyak digunakan oleh para kandidat calon untuk menarik simpati masyarakat Kabupaten Wajo.

\section{Bentuk Partisipasi Pemilih Pemula Dalam Pelaksanaan Pilkada Tahun 2013 Di Kecamatan Tempe Kabupaten Wajo}

Bentuk partisipasi politik seseorang tampak dalam aktivitasaktivitas politiknya, begitu pula dengan pemilih pemula yang berada di
Kecamatan Tempe Kabupaten Wajo. Berdasarkan pernyataan pemilih pemula di Kecamatan Tempe Kabupaten Wajo partisipasi yang mereka lakukan berupa :

1. Pemberian suara

Berkaitan dengan pilkada pemahaman arti demokrasi yang semakin meluas dikalangan masyarakat memberikan pengaruh yang berarti bagi dinamika politik bangsa. Salah satu indikator berjalannya politik secara demokrasi adalah adanya partisipasi masyarakat dalam bidang politik. Untuk mengukur hal itu, kita bisa mengamati bentuk-bentuk partisipasi politik yang ada dalam masyarakat.

Dalam kehidupan masyarakat kita, selalu ada perbedaan-perbedaan yang tidak dapat di hindari. Demikian juga dalam bidang politik, tentunya masingmasing individu memiliki pola fikir dan cara pandanag yang berbeda dalam melihat atau mengartikan persoalan.

Pemilih pemula di Kecamatan Tempe Kabupaten Wajo pada pemilihan kepala daerah 2013 mengalami peningkatan partisipasi. Akan tetapi belum sepenuhnya secara sadar dan mandiri melakukan kegiatan politiknya. Dari hasil observasi dan wawancara dapat di ketahui bahwa mereka memiliki tingkat rasa keingin tahuan yang tinggi, rasa penasaran timbul di karnakan membaca dan melihat serta mendengar iklan atau slogan-slogan yang di iklankan oleh para kandidat atau instansi terkait. Sehingga hal tersebut mendorong pemilih pemula untuk memberikan hak suaranya, mereka tidak ingin melewatkan proses penberian suara karna ingin merasakan memilih wakilnya secara langsung di karnakan Pemilihan kepala daerah 2013 di Kabupaten Wajo merupakan pengalaman pertama bagi pemilih pemula di Kecamatan Tempe. Seperti halnya penuturan dari salah satu 
pemilih pemula di Kecamatan Tempe Kelurahan Tempe Kabupaten Wajo IM 18 tahun, bahwa :

"Saya sering melihat iklan di televisi cara mencontreng dengan benar. Saya merasa penasaran bagaimana rasanya memilih di TPS, karna ini baru pertama kalinya saya ikut memilih". (wawancara IM).

Rasa penasaran atau rasa ingin tahu yang tinggi dari pemilih pemula saat setelah melihat iklan atau pemeberitaan terkait pemilihan umum yaitu cara mencontreng dengan benar menjadi salah satu dorongan yang membuat pemilih pemula yang telah terdaftar sebagai pemilih tetap bersemangat untuk datang ke TPS untuk mengunakan hak pilihnya.

\section{Kampanye}

Kampanye pemilu merupakan sarana pesta demokrasi yang di laksanakan bertujuan untuk mempengaruhi pemilih dalam rangka usaha untuk memperoleh suara sebanyak-banyaknya pada hari pemilihan nanti. Kampanye adalah bagian yang penting dalam kegiatan pemilu, ada berbagai cara yang dilakukan para calon bupati Kabupaten Wajo untuk menarik simpati masyarakat,seperti panggung terbuka, serta pemberian bantuan pembangunan tempat-tempat umum seperti mesjid.

Pemilih pemula kecamatan Tempe Kabupaten Wajo sangat antusias turut serta berpartisipasi dalam kampanye pilkada 2013. Hal ini sesuai dengan wawancara MI 18 tahun pemilih pemula Kecamatan Tempe Kabupaten Wajo, bahwa :

"Saya ikut kampanye bersama teman-teman saya untuk berkumpul mendengarkan pidato dari calon yang saya dukung, setelah itu saya dan teman-teman akan berkeliling kota untuk pawai dengan membawa spanduk calon bupati yang saya dukung".( wawancara MI).

Salah satu bentuk partisipasi pemilih pemula di Kecamatan Tempe Kabupaten Wajo adalah kampanye atau pawai, seperti hasil wawancara di atas alasan para pemilih pemula turut berpartisipasi pada kampanye berbedabeda selain untuk betul-betul berkampanye yang menjadi alasan pemilih pemula turut serta dalam kampanye ialah berkumpul dengan teman-teman mereka.

\section{Berbicara Masalah Politik}

Pada saat akan dilaksanakan pemilihan umum, masyarakat akan suka membicarakan masalah-masalah dan peristiwa-peristiwa politik yang tekait. Meskipun bersifat informal, tidak jarang diskusi-diskusi semacam itu berlangsung menarik. Pada saat diskusi orang bebas mengeluarkan pendapat serta sikapnya. Hal ini di mungkinkan karna adanya hubungan persahabatan serta kekeluargaan di antara peserta diskusi tersebut.

Pemilihan kepala daerah tahun 2013 di Kabupaten Wajo yang merupakan pemilihan umum yang pertama kali di lakukan oleh pemilih pemula di Kecamatan Tempe. Pilkada 2013 di Kabupaten Wajo menjadi hal yang menyenangkan untuk di bicarakan bahkan menjadi bahan diskusi di kalangan para pemilih pemula, mereka sering berdiskusi di sela-sela kegiatan mereka, diskusi-diskusi ringan seperti ini sering terjadi di tempat kerja, tempat bersantai, maupun di tempat kerja, dan pembicaraan ini biasanya dilakukan dengan teman-teman dekat mereka. Seperti yang dikatakan HN 17 tahun pemilih pemula Kecamatan Tempe Kabupaten Wajo, bahwa:

"Saya dan teman-teman sering berkumpul pada saat istirahat 
dan kami membicarkan tentang pemilihan Bupati nanti pada tanggal 18 September 2013 biasanya yang di bicarakan itu tentang siapa yang di perkirakan akan menang pada pemilihan nanti, dan kami juga saling bertanya siapa calon yang akan dipilih nantinya". (wawancara $H N$ ).

Bentuk partisipasi pemilih pemula di Kecamatan Tempe Kabupaten Wajo salah satunya ialah berbicara politik hal ini sering dilakukan oleh para pemilih pemula di tempat kerja atau di lingkungan mereka bergaul.

Hal yang sama juga dikatakan oleh NH 20 tahun pemilih pemula Kecamatan Tempe, bahwa :

"saya biasa bercerita dengan teman kerja saya tentang siapa yang mereka jagokan dalam pemilihan nanti, kami juga biasa membahas alasan-alasan mengapa kami akan memilih calon itu, sehinggah pembicaraan kami akan seru dan menyenangkan karna kami akan membela masing-masing calon yang kami pilih". (wawancara $\mathrm{NH}$ ).

Pemilih Pemula Kecamatan Tempe sering membicarakan atau mendiskusikan masalah pilkada, ini menunjukkan bahwa tingkat partisipasi pemilih pemula Kecamatan Tempe dalam hal berbicara mengenai pilkada bisa di katakan tinggi tingkat partisipasinya dikarenakan membicarakan masalah politik merupakan bentuk partisipasi politik yang mudah untuk dilakukan oleh semua orang.

3. Faktor-Faktor Yang Mempengaruhi Peningkatan Partisipasi Pemilih Pemula Pada Pilkada 2013 Di Kecamatan Tempe Kabupaten Wajo

Kesadaran politik warga negara menjadi faktor determinan dalam partisipasi politik masyarakat, artinya sebagai hal yang berhubungan dengan pengetahuan dan kesadaran akan hak dan kewajiban yang berkaitan dengan lingkungan masyarakat dan kegiatan politik menjadi ukuran dan kadar seseorang terlibat dalam proses partisipasi politik. begitu juga dengan pemilih pemula yang baru memasuki usia hak pilih sebagian besar belum memiliki jangkauan politik yang luas untuk menentukan kemana mereka harus memilih.

Menindak lanjuti hal tersebut, penulis berusaha menggali informasi dari beberapa informan tentang faktor pendorong dan penghambat tingkat partisipasi pemilih pemula pada pilkada 2013 di Kecamatan Tempe Kabupaten Wajo. Adapun yang menjadi faktor penghambat dalam pelaksanaan pilkada yang dialami oleh pemilih pemula yakni:

1) Kesibukan Kegiatan Sehari-hari

Perlu kita ketahui bersama bahwa kelompok pemilih pemula yang berentang usia 17-21 tahun banyak terangkum dalam kalangan pelajar, mahasiswa, dan pekerja muda, begitu pula dengan pemilih pemula yang berada di Kecamatan Tempe yang berentang usia 17-21 tahun rata-rata dari kalangan pelajar, mahasiswa, dan pekerja muda.

Peranan pemilih pemula yang sangat kompleks dalam kegiatan seharihari untuk memenuhi tanggung jawab mereka terhadap pribadinya, selalu menjadi faktor utama yang menghambat keterlibatan mereka dalam kegiatan pemilihan umum. Mereka lebih memilih untuk melaksanakan kegiatan mereka dari pada harus ikut serta dalam urusan pemilu. Hal di ungkapkan oleh RL 19 tahun pemilih pemula Kecamatan Tempe, bahwa :

"Tugas utama saya adalah sekolah, dan kewajiban warga untuk mengsukseskan pilkada adalah untuk memilih dan mencontreng di TPS itu saja 
sudah cukup bagi saya. Kemudian untuk mengurus atau ikut dengan kegiatan yang lain menurut saya sudah ada petugasnya masing-masing dan saya tidak perlu repot untuk ikut terlibat". (wawancara RL).

Melihat pernyataan di atas kita dapat mengetahui bahwa yang menjadikan sebagian pemilih pemula di Kecamatam Tempe enggan berpartisipasi pada kegiatan pilkada di karnakan mereka menganggap dapat menyita waktu yang banyak. Tuntutan sebagai pelajar dan bekerja menjadi alasan utama bagi pemilih pemula enggan turut berpartisipasi.

Kenyataan ini sebenarnya disiasati dengan cara pembagian waktu antara bersekolah dan bekerja dengan melakukan kegiatan politik di masyarakat.

2) Kurang Percaya Diri

Perasaan minder atau merasa tidak mampu ini biasanya di sebabkan oleh tingkat pendidikan yang rendah, kurangnya informasi, dan minimnya pengalaman dalam kegiatan politik, bisa juga dikarnakan tingkat sosial ekonomi yang rendah. Hal ini sesuai dengan pendapat IN 18 tahun pemilih pemula Kecamatan Tempe, bahwa :

"Saya takut dan malu untuk datang di tempat pemilihan, saya takut salah karna saya belum pernah sama sekali ikut memilih". (wawancara IN).

Dari hasil wawancara diatas kita dapat mengentahui bahwa rendahnya tingkat partisipasi pemilih pemula juga di sebabkan oleh perasaan tidak mampu dan kurangnya pengetahuan dan pengalaman, serta kurangnya informasi.

3) Lingkungan Dengan Tingkat

Kesadaran Politik Yang Rendah

Rendahnya tingkat kesadaran seseorang untuk berpartisipasi dalam kegiatan politik seperti pemilu bisa di karnakan seseorang tersebut berada pada lingkungan yang tingkat kesadaran politiknya rendah. Hal ini sesuai dengan pernyataan dari SM 17 tahun pemilih pemula Kecamatan Tempe, bahwa :

"Saya tidak memilih pada saat pemilihan Bupati karna kakak dan ibu saya juga tidak pergi, kami ke kebun panen lombok untuk dijual". (wawancara SM).

Berdasarkan pernyataan diatas kita dapat mengetahui bahwa lingkungan tempat tinggal seseorang bisa menjadi salah satu faktor yang mempengaruhi tinggi rendahnya tingkat partisipasi terhadap kegiatan politik.

Selain faktor penghambat, adapula faktor pendukung yang menjadi pendorong para pemilih pemula dalam berpartisipasi di pesta rakyat (Baca: Pilkada) yakni:

1) Rasa Ingin Tahu

Pemilih pemula ialah kelompok pemilih yang minim pengalaman dalam demokrasi, dari kesemarakan pilkada 2013 di Kabupaten Wajo menjadi sebuah pengalaman tersendiri bagi sebagian kelompok pemilih pemula yang berada di Kecamatan Tempe. Pengalaman yang minin serta pesta demokrasi yang mulai berkembang di Kabupaten Wajo menjadikan pemilih pemula ingin ikut andil dan ingin merasakan secara langsung keterlibatan dalam kegiatan Pilkada. Seperti halnya yang di katakan oleh WH 18 Tahun pemilih Pemula Kecamatan Tempe Kabupaten Wajo, bahwa :

"Pemilihan Bupati 2013 ini adalah pertama kalinya saya terdaftar sebagai pemilih sebelumnya saya hanya dapat melihat orang-orang ke TPS untuk memilih, dan pemilihan bupati tahun ini saya sudah memilih saya ingin merasakan langsung bagaimana rasanya memilih karna itu saya datang 
ke TPS dan mengunakan hak pilih saya pada tanggal 18 September lalu". (wawancara WH).

Salah satu faktor pendorong peningkatan pastisipasi pemilih pemula di Kecamatan Tempe adalah tingginya rasa ingin tahu dari pemilih pemula sehinggah mendorong mereka untuk merasakan secara langsung untuk ikut terlibat dalam pilkada khususnya pada kegiatan pemungutan suara di TPS.

2) Dorongan Atau Bimbingan Dari

Keluarga

Dorongan serta bimbingan dari keluarga merupakan salah satu faktor yang mendorong pemilih pemula Kecamatan Tempe untuk turut berpartisipasi pada pilkada 2013 di Kabupaten Wajo. Hal ini seperti yang di katakan Oleh WR 17 tahun Pemilih pemula Kecamatan Tempe Kabupaten Wajo, bahwa :

"Saya sebagai pemilih pemula yang baru pertama kali memilih sangat terbantu dengan bimbingan dari kakak saya, dia mengajak saya ke TPS untuk memilih dan mengajar saya cara memilih dengan benar di TPS". (wawancara WR).

Dari wawancara di atas kita dapat mengetahui bahwa selain lingkungan yang dapat menjadi faktor tinggi atau rendahnya tingkat partisipasi pemilih pemula di Kecamatan Tempe, Dorongan dan Bimbingan yang positif dari Keluarga juga merupakan salah satu faktor meningkatnya partisipasi pemilih pemula.

\section{E. KESIMPULAN}

Peran media massa dalam peningkatan partisipasi pemilih pemula pada pilkada 2013 di Kecamatan Tempe Kabupaten Wajo yaitu sebagai Pemberi Informasi yaitu media massa memiliki peran yang sangat penting pada peningkatan partisipasi pemilih pemula di karnakan posisinya sebagai pemberi informasi yang banyak di butuhkan masyarakat untuk mendapatkan informasi yang terkait dengan pilkada 2013 di Kabupaten Wajo, media massa juga membantu masyarakat terkhususnya pemilih pemula untuk mempelajari cara berpartisipasi dengan benar pada pilkada. Memperluas pengetahuan yaitu media massa pada pilkada 2013 di Kabupaten Wajo berperan serta untuk membantu masyarakat dan pemilih pemula memperluas wawasan dan pengetahuannya mengenai pemilihan umum sehingga menimbulkan kesadaran masyarakat dan pemilih pemula mengenai fungsinya sebagai warga negara yang memiliki kewajiban untuk berpartisipasi dalam pemilihan umum.

Alat komunikasi media massa menjadi salah satu alat komunikasi massa yang berfungsi membantu memperluas pengetahuan dan memberikan informasi kepada masyarakat yang berkaitan dengan pilkada 2013 di Kabupaten Wajo. Adapun Tingkat partisipasi pemilih pemula Kecamatan Tempe Kabupaten Wajo pada pemilihan kepala daerah tahun 2013 meningkat dan sangat antusis dari pada pemilihan kepala daerah sebelumnya, partisipasi dalam bentuk pemberian suara terbukti dari banyaknya pemilih pemula yang terdaftar pada DPT yang datang ke TPS untuk menggunakan hak pilihnya, partisipasi dalam bentuk kampanye juga mengalami peningkatan walaupun sebahagian pemilih pemula menjadikan kampanye sebagai ajang untuk berkumpul dengan teman-teman mereka.

Begitu pula halnya dengan partisipasi dalam bentuk berbicara masalah politik atau pemilu juga 
mengalami peningkatan walaupun partisipasi dalam bentuk berbicara masalah politik atau pemilu biasanya hanya dilakukan oleh pemilih pemula tertentu saja, hal ini di pengaruhi oleh beberapa faktor di antaranya pendidikan, jenis kelamin, dan status ekonomi sosial dan Faktor-faktor yang mempengaruhi peningkatan partisipasi pemilih pemula di Kecamatan Tempe Kabupaten Wajo selain media massa bimbingan, ajakan serta dorongan dari keluarga atau lingkungan juga yang menjadi salah satu faktor meningkatnya pertisipasi pemilih pemula di Kecamatan Tempe Kabupaten Wajo pada pemilihan kepala daerah 2013 di Kabupaten Wajo.

Saran yang dapat di sampaikan oleh peneliti adalah Pemilih pemula baik yang berada di Kecamatan Tempe Kabupaten Wajo maupun semua pemilih pemula yang berada di Indonesia hendaknya lebih membuka dirinya untuk menunjukkan kemampuannya dalam dunia politik, serta menjauhkan diri dari perasaan minder atau tidak mampu dan dukungan dari keluarga, lingkungan tempat tinggal serta tokoh masyarakat harus di tingkatkan melalui pendidikan politik secara dini pada pemilih pemula sehinggah dapat meningkatkan kualitas peran pemilih pemula dalam partisipasi politik Pemerintah seharusnya menyediakan fasilitas-fasilitas yang dapat mendukung kegiatan pemilih pemula dalam meningkatkan partisipasi dalam dunia politik seperti pemilu, serta pemberian pendidikan politik yang ditunjukkan khusus untuk para pemilih pemula sehinggah dapat merangsang keinginan pemilih pemula untuk ikut berpartisipasi dalam kegiatan politik.

\section{DAFTAR PUSTAKA}

Arifin, 2010. Peran media Massa dalam bidang sosial dan politik. Yokyakarta : pustaka pelajar.

Budiardjo, Miriam, 1994. Demokrasi di Indonesia, Jakarta: PT Gramedia Pustaka Utama..

Effendy, 2009. Keterbukaan Media Massa. Jakarta: Prenada Media.

Haris, 2012. Peran dan peranan Media Massa Dan Komunikasi. Bandung: PT. pustaka sinar harapan.

Ida, Rachmah, 2012. Komunikasi Politik,Media dan Demokrasi.

Pranada Media Group. Jakatra.

Lexy J, Moleong, 1991. Metode Penelitian Kualitatif, Bandung: Remaja Rosda Karya.

Sekertariat Jendral KPU Biro Teknis dan Humas,2010. Modul Pemilih Untuk Pemula, Jakarta : KPU Vol 1 No. 260.

S.H Surandajang. 2013. Pilkada Langsung. Kata penerbit. Jakarta.

Sinaga, Kasturios 2003. Pemilihan Kepala Daerah Langsung Kota, dan Kabupaten. Yogyakarta. Pustaka Pelajar.

Subiagto, Henry 2012. Menggagas Sistem Media Masyarakat yang Demokratis, Jurnal Serjana Komunikasi, Jakarta.

Subiagto Henry, 2012, Wajah Media Massa Kita, Jurnal Aliansi Media Indonesia. Jakarta.

Supono, Sapto 2005, Penyimpangan Pilkada. Bandung. PT. Pustaka Sinar Harapan.

Suyanto Bagong 2005, Metode Penelitian Kualitatif. Bandung PT. Orbit Sakti.

Warsito, 2005. Pengantar Ilmu Komunikasi, Jakarta: Gramedia Widiasarana Indonesia.

William R, Rivers at, 2003. Media Massa dan Masyarakat Modern, Jakarta: Pranada Media.www.kpuwajo.go.id. Diakses tgl 29 Desember 2014. 